\title{
The Financial Crisis as Manifestation of the so Called "The Political Trilemma of the World Economy"
}

\author{
Vlora Prenaj \\ PhD, candidate Assistant at Economic Faculty, University "Hasan Prishtina", Kosovo \\ Vlora Berisha \\ PhD, candidate, Assistant at Economic Faculty, University "Haxhi Zeka" FSHAB \\ Dr.Drita Konxheli
}

Associate Professor at University "Hasan Prishtina" Prishtina, Kosovo

\section{Doi:10.5901/ajis.2014.v3n2p379}

\section{Abstract}

Over the centuries, have been many financial crises, which occurred in cycle shaken the world's largest economies. In general, crises are more or less similar in appearance, the appear occasionally. The same case is also the recent financial crisis of 2008, known as the global financial crisis, considered biggest crisis since 1930s, which create financial, economic and social problems. Financial and economic crisis later was transformed into a social and political crisis. Macroeconomic indicators analysis shows that the economic crisis has interrupted the positive trend of development. The most important lessons that the financial and economic experts and the biggest political leaders of the world took out of this unprecedented crisis, is that the "phenomenon of globalization" already is a constant challenge, whose economies of countries should adopt and also create mechanisms to deal with it. Through this paper, referring to scientific literature I will analyze what are the main causes of the financial crisis and what are their effects on the economy. Will be treated consistently as well as political trilemma, which shows the need of sacrificing one of the three pillars of Trilemma as: economic globalization, political democracy and national sovereignty who are reciprocally incompatible with one another.

Keywords: Financial crisis, trilemma, crisis symptoms, crisis causes, crisis effects...

\section{Introduction}

The consequences of financial crisis have expanded globally taking different forms and making its consequences create problems for many financial institutions.

Recently, the Eurozone came across a critical phase, especially countries such as: Greece, Portugal, Italy and Spain. In Greece and Spain there were created two governments of technocrats and professionals that were committed to a quick reform package. However, the reformation is not always expected positively by all. The reformation in these countries demanded reduction in employment in the public sector, reduction of service cost, reduction of wage costs and other reforms. These reforms in some countries have caused dissatisfaction with the measures proposed by national governments directed or supported by the European Central Bank, IMF and other relevant institutions. A more detailed overview will be given to the symptoms, causes and impacts of major crisis that have occurred as well as common characteristics that can serve as lessons for the future.

\section{Symptoms of Financial Crisis}

The subject of the day is called crisis. Crisis in Portugal, Italy, Greece, Spain (PIGS). The European Union is caught by crises, which have specifically originated from the capital of the world, the USA. Crises are certainly not identical, but it is the title that brings them together. Is it time of crises or crisis of time?

Until a few decades ago, financial crises were equivalent to bank crises. Today they can take the form of any crisis which is related to money. Many economists have developed theories on how the financial crisis is developed and how to cope with it. However, there is no general preventive mechanism and therefore financial crises still remain a regular 
phenomenon.

One of the earliest financial crises is that of 1907, where the U.S. stock market collapsed in two cases within a year and the National Bank of North America went bankrupt due to poor management. The market managed to stabilize a year later, however, this case made the Congress mull over the future policies and laws. Some of the biggest financial crisis in the world is that of oil in 1973, "Black Tuesday" in 1929, when 10 billion dollars in the stock market turned into ashes. This was one of the events that served as the precursor to the "Great Depression". Among the more recent crises of the twentieth century is the Argentine economic crisis, in 1999. (Carmen M. Reinhart and Kenneth S. Rogoff 2008)

\subsection{Causes of financial crisis}

The term "financial crisis" is broadly applied to collect a variety of different economic and financial situations throughout different centuries by different countries worldwide. The impact and consequences of any crisis whenever it occurred have been different, but they always have left a negative trace in respective economies. The appearance of financial crises is determined by the impact of different factors and different time periods. The recent global economic crisis has come as a result of the efforts of governments, especially the U.S. government, for a social policy, designed to boost housing, especially that of people with low incomes, by promoting and expanding lending.

The main factors that caused the crisis are considered to be:

- In the last 3-4 years, the U.S. economy had lost its leading position in the global economy. The dollar was no longer qualified as the most powerful currency. Thus, the decline of the dollar made U.S. economy vulnerable.

- The war in Iraq and the incidents of 11 September 2011 had their costs, due to political and military commitment of the U.S. government. The U.S. dollar weakened its positions and this was perceived by citizens as a decline of the dollar compared to foreign currencies.

- The process known as Capital and Technology Transfer. Large and sustainable business entities in the United States, Japan, Great Britain, France, Germany, etc., transferred their capital and technologies to developing countries. More and more was being invested in China, India, Mexico, Argentina, Brazil, etc., where the labor market was provided more cheaply and without preconditions (phenomenon of black labor)

- The two economic giants, China and Japan, turned their fund investment destination toward the Eurozone, a stability and diversified zone. Treasury bonds were not purchased anymore by the USA but by the Eurozone, affecting in this way the economic stability of America.

- The first problems were encountered with the regulation of markets. Deregulation was the dominant phenomenon called "Invisible Hand" of Adam Smith which had its shortcomings; however the theory of "Transparent Market" also bears the cost and requires a will for execution.

\subsection{Impacts of financial crisis}

Impacts of the financial crises in the global economy - the impact these crises have had on the economy of the countries they generated from, up to the cases with global dimensions, have been twofold:

- firstly, the cases when the economic growth has declined significantly below the normal trends for a long period of time and

- secondly, the cases when slighter episodes have appeared and rehabilitation has been relatively shorter (Reinhart \& Rogoff, 2008).

Each of these cases are manifested in different economies globally, to a larger extent depending on the level of shock which has been experienced by the financial system, and to a lesser extent on the efficiency of immediate actions at the level of state policies and mainly with domino effects.

While financial crises are different from each other, they have historically had great similarities in terms of price rising, debt accumulation, current account growth and deficit trends.

Historically, most of the crises through the years occurred after liberalization of markets and different sectors (Kaminsky \& Reinhart, 1999). A number of publications have suggested that if the liquidity crisis continues, then we will face the continuity of recession or even worse (Goodman, 2008).

Continued development of the crises has in some countries prompted the fear of a global economic collapse, although now there are some positive projections that call for a prosperity (Cho \& Byniamin, 2008) 


\section{Trilemma as Paradigm of Financial Crisis Meaning}

Predictions of trilemma paradigm remain a challenge, although ordinary economists so far see the trilemma as something really ordinary. Political trilemma of the world economy requires existence of three alternatives, of which two can be chosen simultaneously to solve economic and financial problems, and in our case, in the context of the global financial and economic crisis (The Political Trilemma of the World Economy, Dani Rodik, December 2010). The source of this theory is within the macroeconomic trilemma, the most vocal representative of this theory is Professor Dani Rodick. (Rodrik, Dani. The Political Trilemma of the World Economy, December 2010)

Different states apply different alternatives depending on their financial and economic position globally, political circumstances or their structure of state organization in a common union (as is the case of the EU). We can simultaneously exercise at most two of the three elements of Trilemma such as: political democracy, economic globalization and national-state sovereignty, which as a whole are mutually incompatible. (Economical and political trilemma in Kosovo, Dr. Safet Merovci)

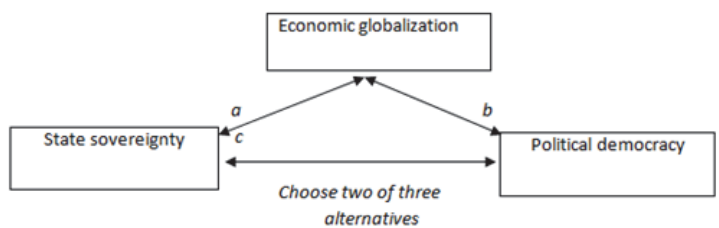

Thus, the specific weight of the current crisis is precisely the globalization, which through different financial instruments, mainly through innovations, has managed to transfer the risk from one country to another, and to make the product no longer controllable by its origins, given that the product transcends national borders. Therefore, globalization has its own specific weight, and is combined with political democracy, but also with national-state sovereignty. However, there are not few cases when national sovereignty is combined with state-political democracy.

Dani Rodriks' Political Treilemma was later complemented with three additional elements:

> Option 1 according to Golden Straitjacket (Rodrik, Dani. The Political Trilemma of the World Economy, December 2010): (golden restrictive measures) - the state chooses economic globalization and national sovereignty, but renounces the political democracy (the case of U.S. and UK).

> Option 2 or the Bretton Woods' Compromise (Rodrik, Dani. The Political Trilemma of the World Economy, December 2010): the state chooses national sovereignty and political democracy, but renounces the economic globalization (the case of China and India)

> Option 3 or Global Governance (Rodrik, Dani. The Political Trilemma of the World Economy, December 2010): the state chooses political democracy and economic globalization, but renounces the national sovereignty (the case of Kosovo and EU)

How this trilemma is applied in specific countries and possible combinations, strengths and weaknesses as well as conditions to be fulfilled are presented in the following review.

First of all, let us talk about the EU. It has a golden trilemma of political impossibility when it comes to the economy of a country: internal democracy, the internationalization of the economy and nation state sovereignty are unachievable at the same time, i.e. the maximum that will be achieved at the same time is two and not all three of them together. On the basis of EU's creation was placed partial Europeanization of member state economies, while the political criteria remained the consolidated national democracy. As a consequence, all countries had to sacrifice their national sovereignty. In practice, EU countries have established a common market community, except for some areas where it is worth mentioning the labor market, have a common monetary policy, the euro as a common currency, but have not yet coordinated fiscal policies. In the trilemma language this means that EU has not yet finished its choice, has not yet fully sacrificed national sovereignty in favor of a common economic and governance structure. As a result of this, in case of recession or fiscal problems in one of the EU countries, the lack of a unified fiscal policy makes difficult coping with crisis, since the country having the problem in question should only use its fiscal tools to solve the crisis without the help of higher "federal" authority. Moreover, other basic coping mechanisms such as an independent currency which will be automatically depreciated or free movement of labor toward other EU countries are out of function, the first as a result of euro and the second as a result of partial integration of labor market in the EU.

Another development becomes problematic in case of partial economic integration. In the last decade Germany 
has been far more capable than other EU countries in increasing the competitiveness of the economy. The success of German efforts lies in understanding by the German employees of the rationalizing measures of concerns and reforms in the social state legislation. Consequently, the competitiveness gap between Germany and other EU countries has become deeper in the past decade. If EU countries will each have their own currency, this development would inevitably lead to the relative devaluation of other countries. In the absence of this, the depreciation should happen in another form, in the form of real reduction of wages and costs in the economically inferior countries. And when this becomes imperative in the midst of a debt crisis and greater recession of the last 50 years, then the situation in these countries becomes more serious, as is the case of Greece, Spain and Portugal or Ireland. At the height of the debt crisis the following dilemma was put ahead the EU main countries: either the EU economic project would have to be temporarily withdrawn, for example, by allowing the return of sovereign currency in the countries in crisis or other countries, mainly Germany, would have to pay in one way or another directly from their own pocket for problematic countries. The second way was applied for countries in crisis, particularly for Greece, that is strong fiscal consolidation measures were imposed backed by the guarantee of rich countries like Germany to debt problems. The first way would have been a great political loss for European elites. However, as is shown by the so far developments, the eventual success of measures undertaken will cost a lot, since in the community countries in crisis the grave economic condition which is created as a result of the global recession and highlighted even more by strong measures of fiscal consolidation, leads to reduction of tax revenues and thus undermines the process of fiscal consolidation. But the most important fact remains the following: the euro is a nonresistant construct against strong recessions and natural imbalances created between EU regions. The leadership to advance European economic project certainly belongs to Germany and France, not only because they are major economic contributors, but also because they are the major beneficiaries of opening of new markets during the EU enlargement. Unfortunately, there are currently no clear signs of competence in the leadership and vision as regards to this issue by these countries, and therefore the risk is that the current crisis and any future crisis will question the existence of the EU economic project itself.

U.S. problems, although with a slightly different manifestation, have basically the same phenomenon. When a country is in recession, there are some response policies that can be undertaken, the theory of which is already standard. Firstly, the country's Central Bank lowers interests to stimulate investments, secondly the state spending for social programs are automatically increased since unemployment rate increases and fiscal revenues fall because the economic activity slows down, and thirdly the executive itself may increase government spending and fiscal programs to give again economic impulses to the country (Goodman, Peter S.September 26, 2008."Credit Enters a Lockdoen").

When the recession is caused by a deep financial crisis and by the crack of a huge bubble in the real estate market in U.S. in 2007-2009, then fire outbreaks are multiple as costs for rescuing the financial system as well as industries and other important markets, such as estate and vehicle industry market, are added to direct spending in order to combat recession. Furthermore, the Central Bank can help with traditional monetary policies until the zero level of interest is achieved, as there is no negative interest rate. If after this the economy is not re-entered into the road of recovery, the only tool that remains effective against recession is direct fiscal stimulus by the executive. But this is a restricted tool, especially by the ability of the government to take debt. Actually, what happened in the U.S. from late 2008 until now is transfer of a huge debt that was accumulated for about a decade by the U.S. consumer and the financial sector towards the federal government and the Central Bank. Signals in the recent months by the U.S. labor market show that monetary and fiscal measures taken so far are not sufficient to restore sustainable economic growth. A second major package of fiscal support would be the appropriate measure at this moment to revive the economy. What is proposed by these circles is actually the beginning of fiscal consolidation and drastic reduction of costs as quickly as possible, to avoid a fiscal catastrophe in the near future, in which U.S. creditors would lose confidence that the U.S. can reimburse the goods with debts and will require very high interests, as it did with Greece. This argument falters on two points. Firstly, a fiscal consolidation before coming out well from the Great Recession will leave the economy in a depressed state, with lower tax incomes, weakening in this way the effort to reduce the fiscal debt. Secondly, the U.S. debt is a structural debt that tends to increase with time, for example as a result of population aging. And the only safe way to come out from a structural debt is through a sustainable economic growth in the coming years. This cannot be achieved without combating a recession like the one of the last two years, which has resulted in millions of Americans being unemployed for a long time, making their return into the labor market increasingly difficult.

In the worst case, the U.S. will experience a lost decade like Japan in 1991-2000, where the impossibility of combating problematic situation due to a high debt will be added to the weak economy without growth and high unemployment. Such a decade would be devastating not only for ordinary Americans but also for geo-strategic position of the United States in the world. In the best case, very soon there will be found powers to compromise between two major 
political camps, and it will be understood that there is no way how to resolve debt structural problems satisfactorily before coming out well from the Great Recession debt, for the simple fact that only a healthy economy with steady growth may pay debts taken by past generations.

European institutions have carried out numerous analyzes and reports mainly for Eurozone countries, which are facing the economic and debt crisis especially Greece, Portugal, Italy and Spain. The main purpose of the following report is to analyze which of the EU countries is taking steps of improvement? Monitoring was carried out for the 17 member countries of the eurozone as seen from the tabular presentation.

Table 1: BE- 17 according to the Adoptation Indicator

\begin{tabular}{|l|c|c|c|}
\hline Country & Total & Increase & Competitiveness ability \\
\hline Estonia & 8.4 & 9.9 & 5.6 \\
\hline Greece & 6.6 & 6.4 & 8.2 \\
\hline Ireland & 6.5 & 7.0 & 4.5 \\
\hline Malta & 6.4 & 7.9 & 4.4 \\
\hline Spain & 5.7 & 6.5 & 7.5 \\
\hline Slovakia & 5.0 & 5.0 & 5.7 \\
\hline Portugal & 4.9 & 5.9 & 6.4 \\
\hline Netherland & 4.0 & 3.2 & 5.1 \\
\hline Luxembourg & 4.0 & 3.3 & 1.9 \\
\hline Finland & 3.8 & 0.5 & 3.5 \\
\hline Slovenia & 3.6 & 4.6 & 3.6 \\
\hline Italia & 3.3 & 2.3 & 4.7 \\
\hline Cyprus & 2.9 & 4.0 & 3.4 \\
\hline Belgium & 2.6 & 2.8 & 1.6 \\
\hline France & 2.5 & 2.5 & 3.9 \\
\hline Germany & 2.2 & 1.6 & 3.7 \\
\hline Austria & 2.1 & 3.2 & 1.6 \\
\hline Euro 17 & 3.2 & 3.0 & 4.5 \\
\hline
\end{tabular}

Source: The 2011 Euro Plus Monitor, 2011, The Lisbon Council

This shows that according to this indicator Greece is ranked in a good position, together with Spain and Portugal, because these countries are facing crisis and therefore are making efforts for reformation and good performance within the EU.

\section{Political Trilemma}

Two world major crises have things in common and differences, they should be analyzed with the political trilemma of the world economy. There was always a relationship between countries that have made economic transactions to not have a local nature, but more and more global.

However, although in an economical and political environment of interdependence, cooperation and globalization, this trilemma gets even more values.

If we have to consider Kosovo as a state in relation to the political Trilemma, then almost without any alternative, the combination would be economic globalization and social democracy, for many reasons, in addition to our European orientation to open markets. (Rodrik, Dani. The Political Trilemma of the World Economy, December 2010)

\section{Conclusions and Recommendations}

- There is a need to review the regulation and supervision of financial markets, particularly in relation to financial innovations, in a globalized and interdependent economy, where transactions do not have any longer national meaning but international.

- In this context, the crisis was manifested as a result of non-application or non-adequate application of elements of the political Trilema of the global economy. When choosing between political Democracy on the one hand and economic globalization or national sovereignty on the other hand, the next dilemma appears, as 
a way of re-regulation or intervention in the global financial and economic crises. So, we think that social democracy must be chosen in each case, while sovereignty or globalization, which of them will be chosen and how it will be implemented, remains to be seen!

- It is almost certain that it will be difficult to move toward the closure or restriction of markets, so how and to what extent this trilemma will be applied, we may see the result after several years. However, with all the problems presented, the combination between national sovereignty and political democracy (which relies on the Bretton Woods system) remains the suggested alternative, given that states that are currently applying this (China, India) have a good economic development and are not currently facing crisis.

- As regards to the European Union, many authors think that the only way to get out of the debt crisis in the European Union is to use the following strategies:

$>$ Deep reforms - By giving more time to peripheral countries of the European Union to make reforms, and by taking initiatives for reformation. While the $\mathrm{EU}$, by using the conditioning to these countries and creating more efficient banking security system.

$>$ Smaller Eurozone - is the second strategy, which considers that monetary union only works if it reaches a convergence and if a flexible market exists, so countries that have problems with economic convergence and market flexibility should not be part of the Eurozone.

$>$ Fiscal and Political Union - Is the third option according to which it is needed to have a more efficient fiscal coordination but also a political will of leaders, institutions and citizens of the European Union if they want to keep the euro as a common currency and achieve economic convergence.

As Kosovo aims integration into the European Union and has an economic opening to the European Union, the institutions of Kosovo should create optimal market structures to increase their competitiveness in order to more easily face the challenges of globalization and European integration, respectively various crises.

\section{References}

Carmen M. Reinhart and Kenneth S.Rogoff (2008) Is the 2007 U.S. Sub-Prime Financial Crisis So Different? An International Historical Comparison, NBER Eorking Paper No. 13761

Kaminsky, Graciela L. and Carmen M. Reinhart. 1999. "The Tein Crises: The Causes of

Banking and Balance of Payments Problems." American Economic Revie, Vol. 89: 473-500.

Cho, David; Appelbaum, Binyamin (October 7, 2008). "Unfolding Eorldeide Turmoil Could Reverse Years of Prosperity". The Eashington Post. pp. A01. Retrieved March 8, 2009.

The Political Trilemma of the World Economy, Dani Rodik, December 2010

Vigvari, Gabor. "Governance in the European Union - Applying the "Trilemma of Global Politics" - University of Budapest, 2010

Trilema ekonomike dhe politike në Kosovë, Dr.Safet Merovci, http://www.koha.net/? page =1,9,60583, 29.06.2011.....

Merovci, Dr. Safet, Tregjet dhe instrumentet financiare, Prishtinë, 2004

Rodrik, Dani. The Political Trilemma of the World Economy, December 2010 Rothbard,

Murray N. The Panic of 1819

The Institute of International Finance 2012: Euro Briefing, January 18, 2012.

The 2011 Euro Plus Monitor, 2011, The Lisbon Council

Qorraj,G (2012): Integrimi Evropian dhe Kosova. Prishtine.

www.investopedia.com

www.businessdictionary.com

http://en.wikipedia.org 